\title{
STUDY OF DETERMINANTS OF PERCEIVED EXPERIENTIAL VALUE FROM LUXURY GOODS RETAIL IN AHMEDABAD CITY
}

\begin{abstract}
:
Luxury goods are defined as conducive to pleasure and comfort and also, hard to obtain. Building on the definition by Vigneron and Johnson (2004), we posit that luxury products can either alternatively or cumulatively - deliver personal indulgence and social esteem on consumers, aside from the functional utility of owning or experiencing a good or service that offers superior value in terms of quality, design, performance, durability and overall customer satisfaction. Hence, by providing exceptional value and overall excellence, luxury products enable consumers to satisfy both or either of their socio-psychological and functional needs (Shukla, 2012; Wiedmann et al., 2007; Hennigs et al., 2012). Customer experience is again a real time concept, experience is more of personal and internal, this concept focuses more on the points of direct and indirect interaction between customer and organisation. Knowing such points of interaction is very vital in delivering complete customer experience. The present study is conducted in the city of Ahmedabad with sample size of 520. All the major luxury goods retailers are covered under the study. Major aim the study is to understand factors determining experiential value while customer is buying luxury goods from such organised retailers.
\end{abstract}

Mrs. Aunkita Sharma

Dr. Nilam panchal

Key Words: Customer Experience, Luxury goods, Perceived Value, Experiential marketing

\section{Introduction}

Luxury is anything that is desirable and more than necessary and ordinary. Defining luxury has been always been very subjective. Scholars explain it dynamically with changing times and scenarios. Luxury is any expenditure that goes beyond the necessaryll, as Werner Sombart begins his essay on the concept and nature of luxury (Sombart, 1992). While the notion that luxury is essentially surplus is acommon one, it has been contested in scholarly debates. Two centuries before Sombart, Mandeville had tackled the definition of luxury against necessity in -The Fable of The Bees\|, his controversial defence of luxury against prevailing moral views of the age. He proposed that in a strict sense, luxury is - everything [...] that is not immediately necessary to make Man subsist $\|$ (Mandeville, 1932).

While Mandeville can be accused of deliberately complicating or even confuse the concept of luxury in challenging what he saw as prejudiced views, his arguments can be said to foreshadow contemporary critique naturalistic or essentialist notions of need and utility (Baudrillard 1993, Appadurai 1986). He lists five characteristics of luxury (Appadurai, 1986), (1) Restriction to elites by law or price (2) Complexity of acquisition - which may or may not reflect 
Aunkita Sharma \& Dr. Nilam Panchal / Page 620-633

real -scarcity (3) Semiotic virtuosity (4)Codes for -appropriatell consumption demanding specialized knowledge 5) High degree of linkage of their consumption to body, person and personality Such a position assumes human needs, at least primary needs, to be fundamental instincts or reflexes and hence ahistorical and acultural (Mortelmans,2005).

The adequate definition of luxury is long overdue for researchers and marketers. Since the 1980s, the luxury market has grown at about ten percent per year, a much higher rate than the world economy, making the luxury industry a relevant economic factor (McKinsey 2011). Estimates of the size of the market for traditional luxury categories including fashion, jewellery and tableware range from about 150 billion $€$ to 200 billion $€$ in 2010 (Bain \& Company 2011). Considering not only traditional luxury categories, but also cars and services such as hotels and travel, the global luxury market is estimated to approach 1 trillion $€$. Despite the current economic uncertainties, Bain \& Company (2011) forecast the luxury market to grow in the next few years by about five to six percent p.a. worldwide and by even more than ten percent p.a. in Asia. High growth rates and the prospect of high margins attract numerous new players into the luxury market (Meffert \& Lasslop 2003). This includes mass-market manufactures aiming to upgrade their products and brands into the luxury segment, as well as a wave of new luxury ventures (Heine 2011). Before they can enter the luxury market, however, these companies need to know what actually constitutes a luxury product or brand.

\section{Literature Review}

We have ample literature on luxury. The recent book on luxury market written by Glyn Atwal, Soumya Jain (2012) — The Luxury Market in India: Maharajas to Masses\| provides strategies to guide brands entering this high-potential market and capture the luxury rupee. - The Cult of the Luxury Brand: Inside Asia's Love Affair with Luxury\| by Radha Chadha and Paul Husband explore how and why an amazing "luxeplosion" is rocking Asia, sweeping up not just the glitzy upper crust, but secretaries toting their Burberry bags, junior executives sporting Rolex watches, and university students in Ferragamo shoes. Hong Kong boasts more Gucci and Hermes stores than New York or Paris. India, the new kid on the luxury block, has three-month waiting lists for hot items, while in Tokyo, the epicenter of the cult, $94 \%$ of women in their 20 s own a Louis Vuitton bag. The cult of the luxury brand is so powerful that Asian consumers account for as much as half of the $\$ 80$ billion global luxe industry.

Radha Chadha and Paul Husband explain the paradox of simultaneously pumping up your product's status while pumping it out to the masses. Other equally important text available on the topic are - Luxury Retail Management: How the World's Top Brands Provide Quality Product and Service Supportl by Michel Chevalier, Michel Gutsatz (2012), Luxury Strategy in Action by Jonas Hoffmann, Ivan Coste-Maniere (2011), Jean-Noel Kapferer, Vincent Bastien (2009) in the book - The luxury strategy: break the rules of marketing to build luxury brands\| highlights that luxury is in fashion. The Luxury Strategy unveils how in any market, including B to B, a company can learn from luxury strategies to differentiate itself profitably. An important book authored by Robin Lent, GenevieveTour (2009) titled -Selling Luxury: Connect with Affluent Customers, Create Unique Experiences through Impeccable Service, and Close the Salell. Michael Boroian, Alix de Poix (2009) in their book - India by Design: The Pursuit of Luxury and Fashion\| intend to say that a rational view of the growing Global Luxury and Fashion Brands market in India. Scholars like Michel Chevalier, Gerald Mazzalovo (2008), Uche 
Okonkwo (2007), Pamela Danziger (2005) gave luxury marketing and strategies that marketers can implement to build their luxury brands.

The concept of social value orientation is rooted in research focusing on co-operation and competition. Presumably, patterns of social value perceptions could be relatively easily understood if individual consumers tended to act in accordance with their own rational selfinterest (Kapferer, 1997). However, in most social interactions such motivations seem to be broader and more multifaceted than the simple quest of personal outcomes (Belk, 1985). Earlier research on social value perceptions indicates that consumers' own choices as well as their expectations of others' choices in outcome-interdependent situations varies as a function of the weight they typically assign to their own and others' outcomes (Tynan et al., 2010). Consumers often acquire products according to what they mean to them and members of their social reference groups (Wiedmann et al., 2007, 2009). Their behaviour is subject to pressures of social norms and expectations of socialisation-oriented institutions such as those arising from family and other reference groups (Shukla, 2012). As Kapferer (1997) observes, the history of luxury consumption is deeply rooted in the notion of social stratification. Shukla (2010) argues that one of the important motivating forces that influence a wide range of consumer behaviour is the aspiration to gain status or social prestige from the acquisition and consumption of goods. Such social value-driven motivations were found to be salient across highly individualistic as well as collectivistic cultures (Shukla, 2012; Vigneron and Johnson, 2004; Wiedmann et al., 2009, Hennigs et al., 2012).

\section{Research Objectives}

1) To study Concept of Experiential Values from Luxury retail stores to customers

2) To Study various determinants of Perceived Experiential values of Luxury retailing for customers

3) To Study various Indicators of the determinants of perceived experiential value of Luxury retailing

4) To evaluate various Factors that forms such Experiential Values form Luxury retailing to the customers

\section{Hypothesis Development}

H0: There is no significant influence of various indicators in development of perceived Experiential Value to the customer.

H1: There is significant influence of various indicators in development of perceived Experiential Value to the customer.

\section{Research Methodology}

Research Methodology explains as how the entire process of research will be carried out to reach at desired research objectives.

\section{a. Research Design}

Research Design is a blue print or complete plan of research, which guides researcher on various aspects of research. Research Design used for this research are Exploratory, Descriptive and causal. 


\section{b. Sampling}

1) Population: Customers of Organised luxury retail in Ahmedabad

2) Sample Size: 520

3) Sampling Method: Non Probability convenience Sampling

\section{c. Contact Method}

Survey method, especially mall intercept was used in the research to collect primary data from respondent

\section{d. Research Instrument}

Structured questionnaire was used to collect data. Questionnaire consists of close ended questions to be evaluated on 5- point likert scale

\section{6) Analysis and Interpretations}

In multivariate statistics, exploratory factor analysis (EFA) is a statistical method used to uncover the underlying structure of a relatively large set of variables. EFA is a technique within factor analysis whose overarching goal is to identify the underlying relationships between measured variables. It is commonly used by researchers when developing a scale (a scale is a collection of questions used to measure a particular research topic) and serves to identify a set of latent constructs underlying a battery of measured variables. It should be used when the researcher has no a priori hypothesis about factors or patterns of measured variables. Measured variables are any one of several attributes of people that may be observed and measured.

Consumer experiential values from Luxury retail were surveyed for their responses for Twenty nine behavioral and attitudinal measures on a Likert-type scale of 1-Strongly disagree through 5-Strongly agree. The same have been used for Factor Analysis to generate a reduced number of factors. Factor analysis is a multivariate method used for data reduction purpose (Malhotra, 2009). The basic idea here is to represent a set of variables by a smaller number of variables called factors. The variables used in factor analysis should be linearly related to each other and preferably measured on interval scale although it can be used for ordinal scale.

\section{Method of Factor Analysis}

Two of the most common methods for Factor Analysis are generally used: (1) Principal Component Analysis, and (2) Common Factor Analysis. Principal component analysis is a method of analysis which involves finding the linear combination of a set of variables that has maximum variance and removing its effect, repeating this successively. Common Factor analysis is a statistical method used to describe variability among observed, correlated variables in terms of a potentially lower number of unobserved variables called factors.

Differentiating between principal component analysis (PCA) and exploratory factor analysis (EFA), Fabrigar et al. (1999) contended that PCA mainly aims to achieve data reduction. That is, its goal is to find a number of factors that are able to represent the original data and make it easier to express, whilst the main purpose of EFA is to identify latent constructs. In other words, 
EFA aims to arrive at a parsimonious representation of the associations among measured variables. This distinction is important especially when we know that data reduction does not attempt to model the structure of correlations among the original variables.

However, some researchers rely on the notion that the results of both PCA and EFA are very similar, so they justify using them interchangeably. However, this point of view is not accepted by other researchers who think that these numerical coincidences are not guaranteed, and therefore, this claim cannot be generalized (Cudeck, 2000). More important, some researchers do not consider PCA as a kind of exploratory factor analysis at all. For example, Cudeck (2000) sees that not only PCA is often incorrectly used as a kind of factor analysis but also many published articles erroneously present PCA results as a type of factor analysis and contends that PCA is mainly a technique for summarizing the information contained in several variables into a small number of weighted composites.

With reference to previous brief discussion, we can say that not principal components analysis (PCA) but exploratory factor analysis (EFA), was considered to be the most appropriate technique for this study scales.

\section{KMO and Bartlett's Test of Sphericity}

Further, before conducting factor analysis, we must check the appropriateness of using this multivariate analysis technique. This can be done using Kaiser-Meyer-Olkin measure of sampling adequacy and Barlett's test of sphericity (Nargundkar, 2003). As recommended by Kaiser, values above 0.7 are good whereas Between 0.5 to 0.7 also acceptable. (cited by Andy Field, 2005). The KMO measures the sampling adequacy which should be greater than 0.5 for a satisfactory factor analysis to proceed. If any pair of variables has a value less than this, consider dropping one of them from the analysis. The off-diagonal elements should all be very small (close to zero) in a good model. Looking at the table below, the KMO measure is 0.709 hence it is inferred that the sample size is the adequate for the factor analysis.

\begin{tabular}{|l|l|l|}
\hline \multicolumn{2}{|l|}{ KMO and Bartlett's Test } & .709 \\
\hline Kaiser-Meyer-Olkin Measure of Sampling Adequacy. & 29169.970 \\
\hline Bartlett's Test of Sphericity & Approx. Chi-Square & \\
\cline { 2 - 3 } & & 406 \\
\cline { 2 - 3 } & Df & 0.000 \\
\cline { 2 - 3 } & Sig. & \\
\hline
\end{tabular}

Barlett's test of sphericity tests the null hypothesis that the original correlation matrix is an identity matrix. For factor analysis, this is an important starting point since the technique is useful only if the variables are correlated. Therefore, for the test to be significant the p-value should be less than 0.05. In this data, the Bartlett's test shows the p-value as 0.000 for chi-square statistic (29169.970) at 406 degrees of freedom and hence the null hypothesis of correlation 
Towards Excellence: An Indexed, Refereed \& Peer Reviewed Journal of Higher Education / Mrs. Aunkita Sharma \& Dr. Nilam Panchal / Page 620-633

matrix being an identity matrix is rejected. Therefore, it is established from the statistical measures that the variables have some correlation and therefore, factor analysis is appropriate

\section{Total Variance Explained}

\begin{tabular}{|c|c|c|c|c|c|c|c|c|c|}
\hline \multirow[b]{2}{*}{$\begin{array}{l}\text { Com } \\
\text { pone } \\
\text { nt }\end{array}$} & \multicolumn{3}{|c|}{ Initial Eigenvalues } & \multicolumn{3}{|c|}{$\begin{array}{l}\text { Extraction Sums of } \\
\text { Squared Loadings }\end{array}$} & \multicolumn{3}{|c|}{$\begin{array}{l}\text { Rotation Sums of Squared } \\
\text { Loadings }\end{array}$} \\
\hline & Total & $\begin{array}{l}\% \text { of } \\
\text { Varian } \\
\text { ce }\end{array}$ & $\begin{array}{l}\text { Cumula } \\
\text { tive } \%\end{array}$ & Total & $\begin{array}{l}\% \text { of } \\
\text { Varian } \\
\text { ce }\end{array}$ & $\begin{array}{l}\text { Cumulat } \\
\text { ive } \%\end{array}$ & Total & $\begin{array}{l}\% \text { of } \\
\text { Varian } \\
\text { ce }\end{array}$ & $\begin{array}{l}\text { Cumulat } \\
\text { ive } \%\end{array}$ \\
\hline 1 & 12.992 & 44.799 & 44.799 & $\begin{array}{l}12.99 \\
2\end{array}$ & $\begin{array}{l}44.79 \\
9\end{array}$ & 44.799 & 4.869 & 16.790 & 16.790 \\
\hline 2 & 3.675 & 12.674 & 57.473 & 3.675 & $\begin{array}{l}12.67 \\
4\end{array}$ & 57.473 & 4.852 & 16.732 & 33.521 \\
\hline 3 & 3.155 & 10.880 & 68.354 & 3.155 & $\begin{array}{l}10.88 \\
0\end{array}$ & 68.354 & 4.268 & 14.717 & 48.239 \\
\hline 4 & 2.771 & 9.556 & 77.910 & 2.771 & 9.556 & 77.910 & 3.955 & 13.637 & 61.875 \\
\hline 5 & 1.379 & 4.755 & 82.665 & 1.379 & 4.755 & 82.665 & 3.839 & 13.239 & 75.114 \\
\hline 6 & 1.137 & 3.921 & 86.587 & 1.137 & 3.921 & 86.587 & 3.327 & 11.473 & 86.587 \\
\hline 7 & .779 & 2.686 & 89.273 & & & & & & \\
\hline 8 & .545 & 1.880 & 91.153 & & & & & & \\
\hline 9 & .503 & 1.735 & 92.888 & & & & & & \\
\hline 10 & .352 & 1.213 & 94.100 & & & & & & \\
\hline 11 & .343 & 1.182 & 95.283 & & & & & & \\
\hline 12 & .263 & .909 & 96.191 & & & & & & \\
\hline 13 & .239 & .825 & 97.016 & & & & & & \\
\hline 14 & .185 & .639 & 97.656 & & & & & & \\
\hline 15 & .159 & .547 & 98.203 & & & & & & \\
\hline 16 & .110 & .379 & 98.582 & & & & & & \\
\hline 17 & .096 & .331 & 98.913 & & & & & & \\
\hline 18 & .079 & .272 & 99.185 & & & & & & \\
\hline 19 & .059 & .204 & 99.389 & & & & & & \\
\hline
\end{tabular}


Towards Excellence: An Indexed, Refereed \& Peer Reviewed Journal of Higher Education / Mrs.

Aunkita Sharma \& Dr. Nilam Panchal / Page 620-633

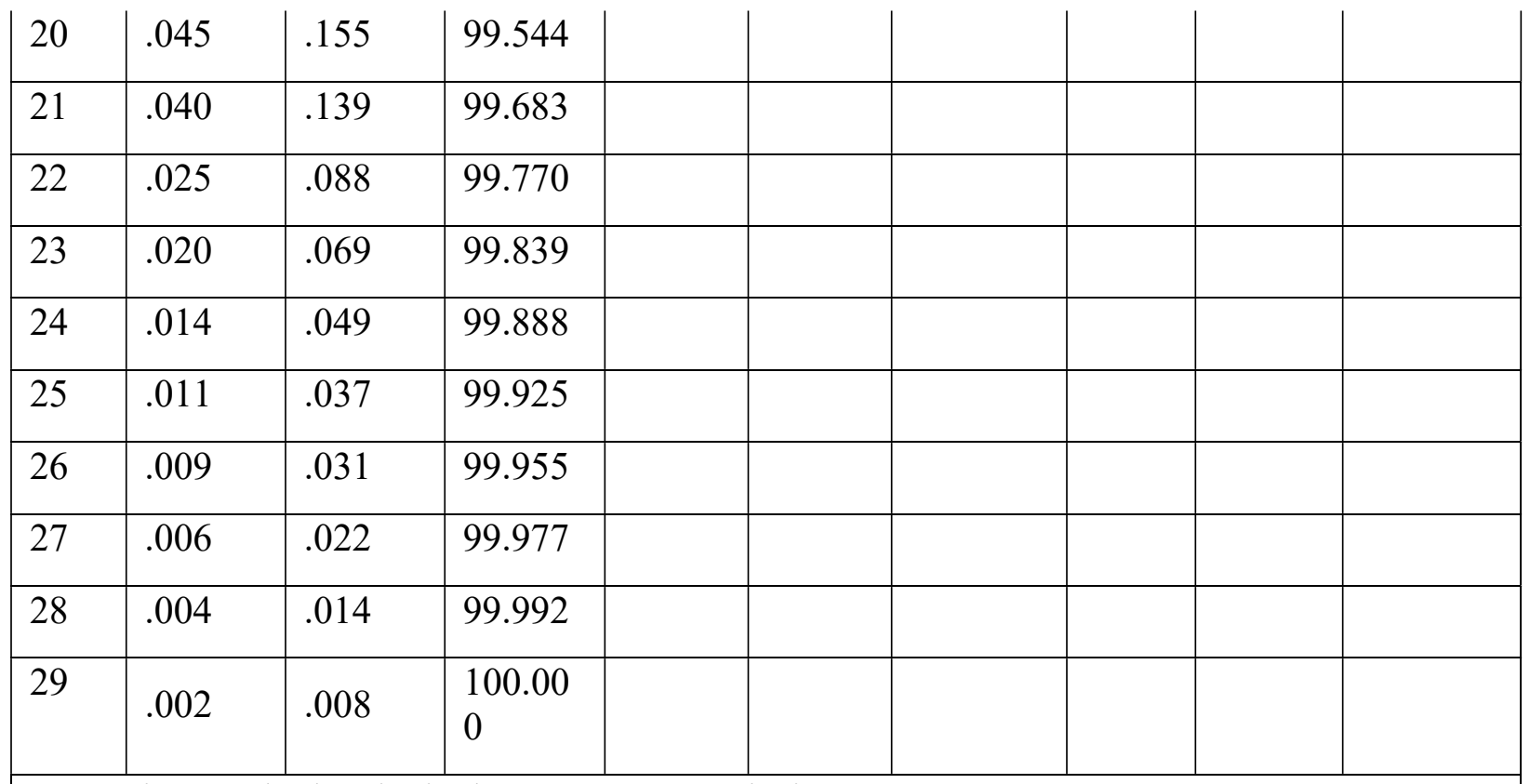

Extraction Method: Principal Component Analysis.

The initial solution was determined using PCA method. A method widely used for determining a first set of loadings. This method seeks values of the loadings that bring the estimate of the total communality as close as possible to the total of the observed variances.

Table lists the Eigen values, associated with each linear component (factor) before extraction, after extraction and after rotation. All factors with Eigen values greater than 1 are extracted which leaves us with 29 variables reduced to six factors. Rotation has the effect of optimizing the factor structure and one consequence for these data is that the relative importance of six factors is equalized. First factor explain approximately $44.799 \%$ of variance and other five factor also explain the significantly high variance. Also, it shows a cumulative percentage of $87 \%$ of the total variance explained by the six factors and leaving $13 \%$ of the variance to be explained by the other 23 components.

Using Kaiser's criterion, the study sought variables with eigenvalues greater than or equal to 1. The first six components had eigenvalues greater than or equal to 1 and accounted for 87 percent of the variance, with component 1 accounting for 44.799 percent of the variance, component 2 explained 12.674 percent of the variance, component 3 explained 10.880 percent of the variance, component 4 explained 9.556 percent of the variance, component 5 explained 4.755 percent of the variance and last component explained approximately 4 percent of the variance. Therefore based on the total variance explained analysis, a maximum of 6 components could be extracted from the combined data set.

The Kaiser criterion has a weakness as observed by Nunny and Berstein (1994) as its tendency to overstate the number of factors. Stevens (2002) proposes the use of a scree plot in determining the number of components to retain. The scree plot graphs the eigenvalues against the component number and displays a point of inflexion on the curve, which can be used in 
determination of number of components to extract. In a scree plot, the components before this point indicate the number of factors to retain while the components after the point of inflexion show that each successive factor is accounting for smaller and smaller amounts of variations hence should not be retained.

The rotated component matrix shows the factor loadings of each variable onto each factor. Factor loadings less than 0.4 have not been displayed. As cited by Field (2009), the original logic behind suppressing loadings less than 0.4 is based on Stevens' suggestion that this cut-off point is appropriate for interpretative purposes (i.e. the loadings greater than 0.4 represent substantive values.)

The rotated component matrix helps to determine what the factors represent as the factor loadings denote the correlation (coefficients) between the variable and the factor. The object of the rotation is to ensure that all the variables have high loadings only on one factor. While the researcher has the option of selecting from the two rotation methods: Orthogonal and Oblique; the first method has been selected here so that the rotated factors remain uncorrelated. For this purpose, the rotation method used is 'Varimax'.

Larger loadings on a single factor help to interpret the underlying factor. Finally, the factor analysis procedure gives six factors reduced from 29 variables.

\begin{tabular}{|l|l|l|l|l|l|l|}
\hline Rotated Component Matrix \\
\hline
\end{tabular}


Towards Excellence: An Indexed, Refereed \& Peer Reviewed Journal of Higher Education / Mrs. Aunkita Sharma \& Dr. Nilam Panchal / Page 620-633

\begin{tabular}{|c|c|c|c|c|c|}
\hline $\begin{array}{l}\text { Brands in this shop/store make a strong impression } \\
\text { on my senses. }\end{array}$ & & & & & 680 \\
\hline The brand in this shop/store appeals to my senses. & & & & & .623 \\
\hline $\begin{array}{l}\text { The brand in this shop/store influences my } \\
\text { feelings. }\end{array}$ & & & & & .778 \\
\hline $\begin{array}{l}\text { There is a feel good factor in the brands I buy in } \\
\text { this shop/store. }\end{array}$ & & & & & .666 \\
\hline $\begin{array}{l}\text { The Brand I buy from this store influence my } \\
\text { behaviour }\end{array}$ & & & & & .786 \\
\hline Prices in this shop/store are reliable. & & .849 & & & \\
\hline Prices in the store/shop are reasonable & & .763 & & & \\
\hline $\begin{array}{l}\text { The price in this shop/store is a true representation } \\
\text { of the value of the goods. }\end{array}$ & & .835 & & & \\
\hline $\begin{array}{l}\text { The prices in this shop/store are representing the } \\
\text { true quality of the goods. }\end{array}$ & & .847 & & & \\
\hline $\begin{array}{l}\text { The goods in this shop/store are worth the money } \\
\text { paid. }\end{array}$ & & .746 & & & \\
\hline People in the store/shop influence me & & & & .803 & \\
\hline People respond to my emotional needs. & & & & 678 & \\
\hline I feel happy when I visit the shop/store. & & & & .736 & \\
\hline It is a comfortable feeling in the shop/store. & & & & .877 & \\
\hline The service personnel are professional. & & & .857 & & \\
\hline $\begin{array}{l}\text { The service interface is completely customized to } \\
\text { my purchase requirements. }\end{array}$ & & & .857 & & \\
\hline I receive tailor made solution for all my enquiries. & & & .722 & & \\
\hline $\begin{array}{l}\text { My behaviour is influenced by the service } \\
\text { provided to me }\end{array}$ & & & .839 & & \\
\hline $\begin{array}{l}\text { The service interface has helped me resolving } \\
\text { retailing issues. }\end{array}$ & & & .716 & & \\
\hline $\begin{array}{lcc}\text { Extraction } & \text { Method: } & \text { Principal } \\
\text { Rotation Method: Varimax with Kaiser Normalizat }\end{array}$ & & Component & & & alysis. \\
\hline
\end{tabular}


A Varimax with Kaiser Normalization rotation method revealed a six component structure as shown in Table. The original 29 items in the instrument had been loaded on the seven components.

Component one had 5 items loading on it with the item, "The temperature control in the store is comfortable." reflecting the highest factor loading of $(0.923)$, followed by "The Atmosphere makes me feel Active" (0.915), "The aroma in the shop/store is likable." (0.850), "The aesthetics of the shop/store is appealing." (0.835) and "The looks of the shop/store is appealing." (0.820). The 5 items converged on the factor Retail atmosphere.

Surrogate variable which is selection of a single variable with the highest factor loading to represent a factor in the data reduction stage instead of using a summated scale or factor score, is "The temperature control in the store is comfortable.." reflecting the highest factor loading of 0.923."

A set of 5 items loaded on component two. The item that explained the greatest variations in component two were, "The attributes of product assortment adequately differentiate each other." (0.931), "The store/shop has number of versions in a single product" (0.927), "Under each assortment there are a sizable number of favorites." $(0.811)$ "The space provided for display of different items in a product is adequate." (0.784) and "Each brand in an assortment has unique features." (0.769). The 5 items that loaded on component two were interpreted as the factor Assortment.

A total of five items loaded on component three. The greatest variations in component three was explained by the items "Prices in this shop/store are reliable." (0.849), followed by "The prices in this shop/store are representing the true quality of the goods." $(0.847)$, "The price in this shop/store is a true representation of the value of the goods." $(0.835)$, "Prices in the store/shop are reasonable" $(0.763)$ and "The goods in this shop/store are worth the money paid" (0.746).A close examination of the 5 items led to their interpretation as the factor price and the item "Prices in this shop/store are reliable", is the surrogate variables of Price.

Component four had five items loading on it. The item with the highest factor loading was, "The service personnel are professional." (0.857) followed by "The service interface is completely customized to my purchase requirements." (0.857), "My behaviour is influenced by the service provided to me" (0.839), "I receive tailor made solution for all my enquiries." $(0.722)$, and "Service provided by my bank is competitive enough." $(0.716)$. the five items were interpreted as the factor Service Interface.

Four items loaded on component five. "It is a comfortable feeling in the shop/store." (0.877), followed by "People in the store/shop influence me" $(0.803)$, "I feel happy when I visit the shop/store." (0.736), "People respond to my emotional needs." (0.678). the four items were interpreted as the factor Social and surrogate variable for Social is "I have faith in my service provider to solve the conflict handling (0.863)."

Five items loaded on component six. "The Brand I buy from this store influence my behaviour (0.786), followed by "The brand in this shop/store influences my feelings $(0.778)$, "Brands in this shop/store make a strong impression on my senses." (0.680), "There is a feel good factor in the brands I buy in this shop/store. " $(0.666)$, and "The brand in this shop/store 
appeals to my senses." (0.623). the five items were interpreted as the factor Brand and surrogate variable for Brand is "The Brand I buy from this store influence my behaviour (0.786).

\section{Conclusion}

Thus the based upon exploratory factor analysis, it is possible to draw insightful inferences for the data collected from the primary survey. Six factors are extracted from the quantitative analysis. Explored relationship marketing factors are Retail atmosphere, Assortment, Price, Service interface, Social and brand. Further this research confer this explored variable and later on tries to establish structural causal model of consumer experiential values from Luxury retail. 


\section{References}

Ait-Sahalia, Y., Parker, J.A. and Yogo, M. (2004) 'Luxury goods and the equity premium', Journal of Finance, Vol. 59, No. 6, pp.2959-3004.

Allen, K. (2007) 'Despite the turmoil, conspicuous consumption is still in vogue', The Guardian [online] http://business.guardian.co.uk/story/0,,2160310,00.html (accessed 28 September 2010).

Beatty, S.E. and Ferrell, M.E. (1998) 'Impulse buying: modelling its precursors', Journal of Retailing, Vol. 74, No. 2, pp.161-167.

Belk, R.W. (1985) 'Materialism: trait aspects of living in the material world', Journal of Consumer Research, Vol. 12, No. 3, pp.265-280.

Bennett, J.L. (1984) 'Managing to meet usability requirements: establishing and meeting software development goals', in Bennett, J.L., Case, D., Sandelin, J. and Smith, M. (Eds.): Visual Display Terminals: Usability Issues and Health Concerns, pp.161-184, Prentice Hall, Englewood Cliffs.

Chattalas, M. and Garcia, C. (2009) 'The effects of collectivism on utilitarian versus selforiented luxury consumption', Proceedings of the European Marketing Academy Annual Conference, Nantes, France.

Cornell, A. (2002) 'Cult of luxury: the new opiate of the masses', Australian Financial Review, 27 April, p.47.

Cronin, J. and Taylor, S. (1992) 'Measuring service quality: a re-examination and extension',

Journal of Marketing, Vol. 56, No. 3, pp.55-68.

Datamonitor (2009) Apparel, Accessories \& Luxury Goods Industry Profile: Global, Datamonitor, London.

Dillion, W.R. and Goldstein, M. (1984) Multivariate Analysis: Methods and Applications, Wiley, New York.

Douglas, S.P. and Craig, S.C. (1983) International Marketing Research, Prentice-Hall, Englewood Cliffs.

Dubois, B. and Laurent, G. (1994) 'Attitudes toward the concept of luxury: an exploratory analysis', Asia-Pacific Advances in Consumer Research, Vol. 1, No. 2, pp.273-278.

Dubois, B., Czellar, S. and Laurent, G. (2005) 'Consumer segments based on attitudes toward luxury: empirical evidence from twenty countries', Marketing Letters, Vol. 16, No.

2, pp.115-128.

Durvasula, S., Andrews, C.J., Lysonski, S. and Netemeyer, R.G. (1993) 'Assessing the cross-national applicability of consumer behavior models: a model of attitude toward advertising in general', Journal of Consumer Research, Vol. 19, No. 4, pp.626-636.

Eastman, J.K., Goldsmith, R.E. and Flynn, L.R. (1999) 'Status consumption in consumer behaviour: scale development and validation', Journal of Marketing Theory and Practice, Vol. 7, No. 3, pp.41-51.

Economist (2009) LVMH in the Recession: The Substance of Style [online] http://www.economist. com/displaystory.cfm?story_id=14447276 (accessed 14 October 2010).

Fornell, C. and Larcker, D.F. (1981) 'Evaluating structural equation models with unobservable variables and measurement error', Journal of Marketing Research, Vol. 18, No. 1, pp.39-50.

Glare, P.G.W. (1992) Oxford Latin Dictionary, Clarendon Press, Oxford. 
Gower, I. (2008) Market Forecasts: Clothing \& Personal Goods, Key Note, London. Han, S.H., Hwan Yun, M., Kim, K.J. and Kwahk, J. (2000) 'Evaluation of product usability: development and validation of usability dimensions and design elements based on empirical models', International Journal of Industrial Ergonomics, Vol. 26, No. 4, pp.477-488.

Hennigs, N., Wiedmann, K.P., Klarmann, C., Strehlau, S., Godey, B., Pederzoli, D., Neulinger, A., Dave, K., Aiello, G., Donvito, R., Taro, K., Taborecka-Petrovicova, J., Santos, C.R., Jung, J. and Oh, H. (2012) 'What is the value of luxury? A cross-cultural consumer perspective', Psychology \& Marketing, Vol. 29, No. 6, pp.1018-1034.

Hofstede, G. (1991) Cultures and Organizations: Software of the Mind, McGraw-Hill, London. Hofstede, G. and Hofstede, G.J. (2004) Cultures and Organizations: Software for the Mind, McGraw-Hill, London.

Kapferer, J.N. (1997) 'Managing luxury brands', Journal of Brand Management, Vol. 4, No. 4, pp.251-260.

Litvin, S.W. and Kar, G.H. (2004) 'Individualism/collectivism as a moderating factor to the self-image congruity concept', Journal of Vacation Marketing, Vol. 10, No. 1, pp.23-32. Mason, R.S. (1999) The Economics of Conspicuous Consumption: Theory and Thought Since 1700, Edward Elgar Publishing, London.

Nueno, J.L. and Quelch, J.A. (1998) 'The mass marketing of luxury', Business Horizons, Vol. 41, No. 6, pp.61-68.

Nunnally, J.C. (1978) Psychometric Theory, 2nd ed., McGraw-Hill, New York.

O'Cass, A. and Frost, H. (2002) 'Status brands: examining the effects of non-product-related brand associations on status and conspicuous consumption', Journal of Product \& Brand Management, Vol. 11, No. 2, pp.67-88.

O'Cass, A. and McEwen, H. (2004) 'Exploring consumer status and conspicuous consumption',

Journal of Consumer Behaviour, Vol. 4, No. 1, pp.25-39.

Pallant, J. (2004) SPSS Survival Manual: Version 12, Open University Press, New York.

Phau, I. and Prendergast, G.P. (1999) Consuming Luxury Brands: The Relevance of the 'Rarity Principle', Hong Kong Baptist University Business Research Centre, Hong Kong.

Shukla, P. (2010) 'Status consumption in cross-national context: socio-psychological, brand and situational antecedents', International Marketing Review, Vol. 27, No. 1, pp.108-129.

Shukla, P. (2012) 'The influence of value perceptions on luxury purchase intentions in developed and emerging markets', International Marketing Review, Vol. 29, No. 6, pp.574596.

Shukla, P. and Purani, K. (2012) 'Comparing the importance of luxury value perceptions in cross- national contexts', Journal of Business Research, Vol. 65, No. 10, pp.1417-1424.

Singh, J. (1995) 'Measurement issues in cross-national research', Journal of International Business Studies, Vol. 26, No. 3, pp.597-619.

Steenkamp, J-B.E.M. and Baumgartner, H. (1998) 'Assessing measurement invariance in cross-national consumer research', Journal of Consumer Research, Vol. 25, No. 1, pp.78107.

Strizhakova, Y., Coulter, R.A. and Price, L.L. (2008) 'Branded products as a passport to global citizenship: perspectives from developed and developing markets', Journal of International Marketing, Vol. 16, No. 4, pp.57-85.

Trompenaars, A. and Hampden-Turner, C. (1998) Riding The Waves of Culture: Understanding Diversity in Global Business, McGraw-Hill, London. 
Truong, Y., Simmons, G., McColl, R. and Kitchen, P.J. (2008) 'Status and conspicuousness - are they related? Strategic marketing implications for luxury brands', Journal of Strategic Marketing, Vol. 16, No. 3, pp.189-203.

Tsai, S.P. (2005) 'Impact of personal orientation on luxury-brand purchase value', International Journal of Market Research, Vol. 47, No. 4, pp.177-206.

Tynan, C., McKechnie, S. and Chhuon, C. (2010) 'Co-creating value for luxury brands', Journal of Business Research, Vol. 63, No. 11, pp.1156-1163.

Vigneron, F. and Johnson, L.W. (2004) 'Measuring perceptions of brand luxury', Journal of Brand Management, Vol. 11, No. 6, pp.484-508.

Voss, K.E., Spangenberg, E.R. and Grohmann, B. (2003) 'Measuring the hedonic and utilitarian dimensions of consumer attitude', Journal of Marketing Research, Vol. 40, No. 3, pp.310-320.

Wiedmann, K.P., Hennigs, N. and Siebels, A. (2007) 'Measuring consumers' luxury value perception: a cross-cultural framework', Academy of Marketing Science Review, Vol. 7, pp.1-21.

Wiedmann, K.P., Hennigs, N. and Siebels, A. (2009) 'Value-based segmentation of luxury consumption behavior', Psychology and Marketing, Vol. 26, No. 7, pp.625-651.

Wong, N.Y. and Ahuvia, A.C. (1998) 'Personal taste and family face: luxury consumption in Confucian and western societies', Psychology \& Marketing, Vol. 15, No. 5, pp.423-441.

Zaichkowsky, J.L. (1985) 'Measuring the involvement construct', Journal of Consumer Research, Vol. 12, No. 3, pp.341-352.

Zeithaml, V.A. (1988) 'Consumer perceptions of price, quality, and value: a means-end model and synthesis of evidence', Journal of Marketing, Vol. 52, No. 1, pp.2-22.

Mrs. Aunkita Sharma

Research Scholar

B.K. School of Professional and Management Studies

Gujarat University

\&

Dr. Nilam panchal

Associate Professor \& Head- Department of Public Policy and Governance

B.K. School of Professional and Management Studies

Gujarat University 